\title{
Cherry Shrimp Neocaridina davidi (Bouvier 1904) (Crustacea: Decopoda: Atyidae) ${ }^{1}$
}

\author{
Carrie Suen and Jennifer L. Gillett-Kaufman²
}

\section{Introduction}

Neocaridina davidi is a species of freshwater ornamental shrimp that belongs to the Atyidae family. Neocaridina davidi originates from Taiwan, but the popularity of colorful freshwater shrimp has led to them being available in other countries via the aquarium trade. This shrimp has different common names based on its color (see synonymy section). Wild-type shrimp are generally transparent or greenish-brown; however, generations of selective breeding have produced a variety of colors and patterns (Figure 1).

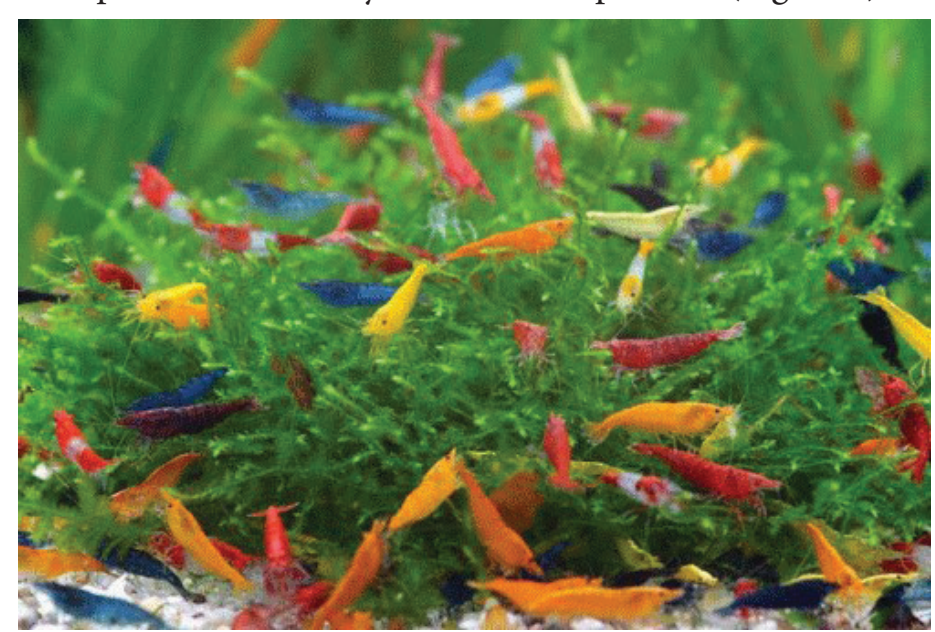

Figure 1. Common color morphs of Neocaridina davidi (Bouvier). Credits: Chris Lukhaup

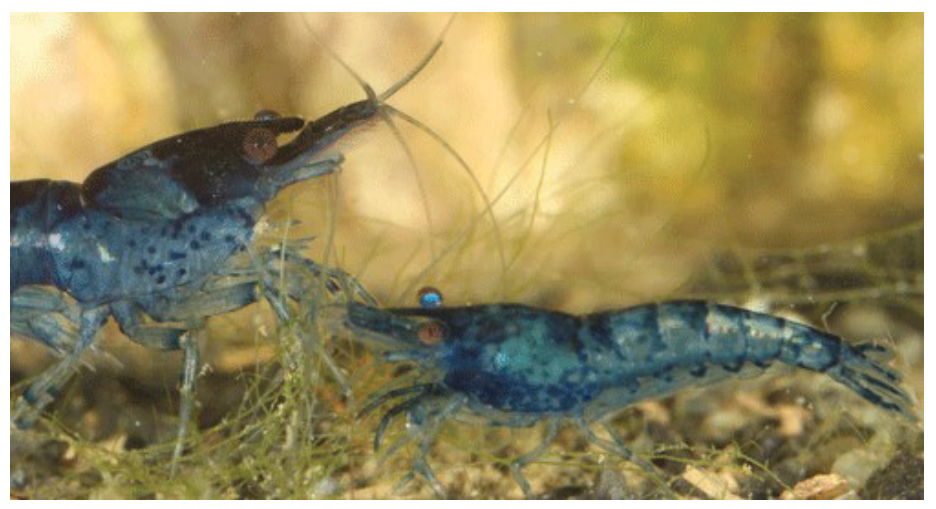

Figure 2. Blue color morph of Neocaridina davidi (Bouvier). Credits: Lyle J. Buss, UF/IFAS

\section{Synonymy}

Neocaridina denticulata sinensis (Kemp 1918)

Neocaridina heteropoda (Liang 2002)

Common morph names of Neocaridina davidi:

Red morph: cherry shrimp

Orange morph: orange sakura shrimp

Yellow morph: yellow sakura shrimp

Green morph: green jade shrimp

Blue morph: blue dream, blue velvet, and blue jelly

1. This document is EENY-751, one of a series of the Entomology and Nematology Department, UF/IFAS Extension. Original publication date March 2020. Visit the EDIS website at https://edis.ifas.ufl.edu for the currently supported version of this publication. This document is also available on the Featured Creatures website at http://entomology.ifas.ufl.edu/creatures.

2. Carrie Suen and Jennifer L. Gillett-Kaufman, Extension scientist; Entomology and Nematology Department, UF/IFAS Extension, Gainesville, FL 32611.

The Institute of Food and Agricultural Sciences (IFAS) is an Equal Opportunity Institution authorized to provide research, educational information and other services

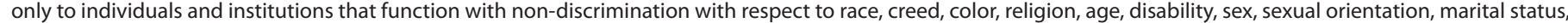

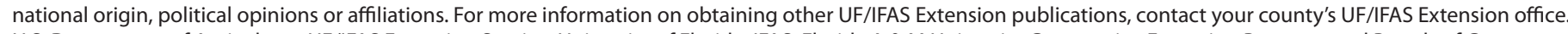
U.S. Department of Agriculture, UF/IFAS Extension Service, University of Florida, IFAS, Florida A \& M University Cooperative Extension Program, and Boards of County Commissioners Cooperating. Nick T. Place, dean for UF/IFAS Extension. 


\section{Distribution}

Neocaridina davidi is native to freshwater streams of Taiwan. Cherry shrimp normally live in tropical waters, but Neocaridina davidi populations have been observed as far north as Poland in thermally polluted canals, likely as a result of release (Jablonska et al. 2018). Thermal pollution refers to the changing of ambient water temperatures from human activities, such as occurs when water is released after being used to cool power and manufacturing plants. In addition to Poland, these shrimp have also been discovered in the thermally polluted Erft and its tributary Gillbach Rivers in Germany (Klotz et al. 2013), as well as in the rivers of eastern Japan (Mitsugi and Suzuki 2018). In the case of Poland and Germany, there are no indigenous shrimp species in the area, so it is uncertain what effects they might have on the local biome, as well as long term changes to the ecosystem. An exotic population of Neocaridina davidi was observed in freshwater systems in Israel. These shrimp have been observed in the Jordan River, Yarqon Stream, and the HaHula Nature Reserve (Levitt-Barmats et al. 2019). Cherry shrimp primarily feeds on leaf litter on the bottom of the rivers, with alder (Alnus glutinosa) and goat willow (Salix caprea) being the preferred varieties (Schoolman and Arndt 2017).

In addition to being an introduced species in Europe and Asia, populations of Neocaridina davidi have been reported on the island of Oahu in Hawaii since 1991. Populations were found in multiple streams, springs, and reservoirs such as the Waikele Spring, Ho'omaluhia Reservoir, and the Nu'uanu Reservoir (Englund 1999). Neocaridina davidi was found most commonly in waters with the highest velocities. It is believed that these shrimps were introduced through the aquarium trade, either through accidental or intentional release. Neocaridina davidi occupies similar freshwater habitats to some shrimp species and may compete with them for resources, thus threatening the native Hawaiian shrimp species. Native atyid shrimp species, such as Atyoida bisulcate, are listed as a near-threatened species by the International Union for Conservation of Nature (IUCN) Red List (De Grave and Cai 2013).

\section{Description and Life Cycle}

Ornamental shrimp such as Neocaridina davidi grow to a maximum adult size of 3 to 4 centimeters in length, and females are typically larger than males likely due to the fact that females carry the eggs to term under their bodies (Figures 3 and 4). In the aquarium trade, the female shrimp that are carrying eggs are referred to as berried.

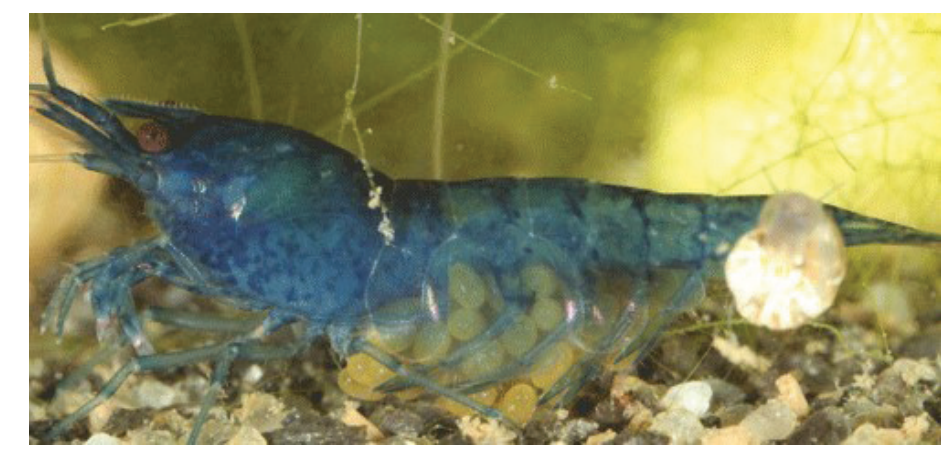

Figure 3. A female cherry shrimp, Neocaridina davidi (Bouvier), with eggs.

Credits: Lyle J. Buss, UF/IFAS

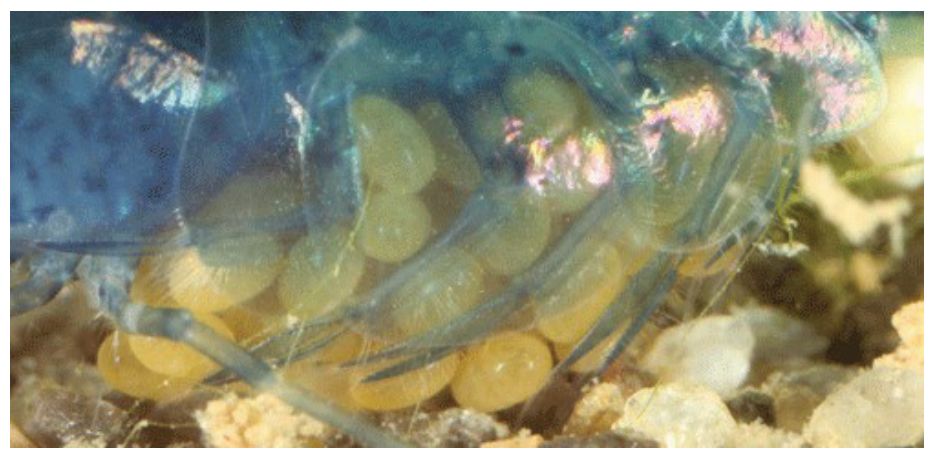

Figure 4. Cherry shrimp, Neocaridina davidi (Bouvier), eggs being held by a female shrimp.

Credits: Lyle J. Buss, UF/IFAS

Neocaridina davidi has a similar anatomy to marine shrimp. The differences lie in the shape of certain structures.

Belonging to the order Decapoda, Neocaridina davidi have five pairs of walking legs called periopods. The first two pair of legs are modified structures called chelate, which are claw-like appendages used for grabbing food. In front of the periopods are three pairs of maxillipeds or jaw legs used for feeding. Under the abdomen are five pairs of limbs that are used for swimming, called pleopods. In female shrimp, these limbs are also used for egg holding. The rostrum, or beak, of the cherry shrimp has a more squared shape compared to the more pointed shape found in saltwater shrimp species. Like most shrimp species, ornamental shrimp are detritivores and opportunistic feeders. They will graze on algae, biofilms, and dead plants and animals on the bottoms of rivers.

Freshwater shrimp reproduce sexually, with the female carrying the eggs under her body with her legs until they are ready to hatch (Figures 2 and 3 ). The eggs are held underneath the female's abdomen where the pleopods, the swimming legs, clean the eggs to prevent fungal growth. The incubation time for the eggs ranges from 16 to 19 days. The clutch size a female can carry ranges between 43 to 60 eggs (Pantaleão et al. 2015). 
Unlike most crustaceans, this shrimp does not have a larval stage. The young of this species emerge from the eggs as miniature versions of the adult, they are only around 1 to 2 millimeters in length. As with all arthropods, Neocaridina davidi grows by molting their exoskeleton (Figure 5). They will feed on their molted exoskeleton to reabsorb valuable nutrients. Sexual maturity is reached at around 30 days.

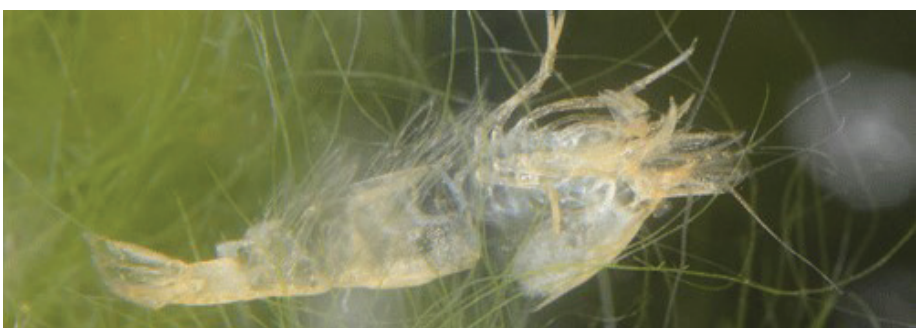

Figure 5. Molt (cast exoskeleton) of a cherry shrimp, Neocaridina davidi (Bouvier).

Credits: Lyle J. Buss, UF/IFAS

\section{Behavior}

Neocaridina davidi spends the majority of its time grazing on biofilms that form on leaf litter. Like most crustaceans, shrimp play a crucial role in the aquatic ecosystem by serving as a food source for other organisms and by recycling nutrients through feeding on decaying vegetation. This helps keep the water clean. Neocaridina davidi also feeds on meiofauna, which are small microorganisms that live in benthic (bottom) regions. Examples of meiofauna include, but are not limited to, nematodes, rotifers, tardigrades, and ciliates. In a study using a microcosm, researchers found evidence of Neocaridina davidi predating on meiofauna species through an analysis of stomach contents. Overall, Neocaridina davidi reduced the abundancy and biomass of meiofaunal organisms in the stimulated microcosm (Weber and Traunspurger 2016).

\section{Selected References}

De Grave S, Cai Y. 2019. Atyoida bisulcata. The IUCN Red List of Threatened Species. DOI: http://dx.doi.org/10.2305/ IUCN.UK.2013-1.RLTS.T198132A147794954.en

Englund RA. 1999. "The occurrence and description of Neocaridina denticulata sinensis (Kemp, 1918) (Crustacea: Decapoda: Atyidae), a new introduction to the Hawaiian Islands." Bishop Museum Occasional Papers 58: 58-65.

Jablonska A, Mamos T, Gruszka P, Szlauer-Lukaszewska A, Grabowski M. 2018. "First record and DNA barcodes of the aquarium shrimp, Neocaridina davidi, in central Europe from thermally polluted River Oder Canal, Poland." Knowledge and Management of Aquatic Ecosystems 419: 14.
Klotz W, Miesen FW, Hüllen S, Herder F. 2013. “Two Asian freshwater shrimp species found in a thermally polluted stream system in North Rhine-Westphalia, Germany." Aquatic Invasions 8: 333-339.

Levitt-Barmats Y, Yanai Z, Cohen TM, Shenkar N. 2019. "Life-history traits and ecological characteristics of the ornamental shrimp Neocaridina denticulata (De Haan, 1844), recently introduced into the freshwater systems of Israel." Aquatic Invasions 14: 684-702.

Mitsugi M, Suzuki H. 2018. "Life history of an invasive freshwater shrimp Neocaridina davidi (Bouvier, 1904), (Decapoda: Caridea: Atyidae) in the Tomoe River, the Boso Peninsula, eastern Japan." Crustacean Research 47: 9-16.

Pantaleão JAF, Gregati RA, da Costa RC, Lopez-Greco LS, Negreiros-Fransozo ML. 2015. "Post-hatching development of the ornamental 'Red Cherry Shrimp' Neocaridina davidi (Bouvier, 1904) (Crustacea, Caridea, Atyidae) under laboratorial conditions." Aquaculture Research 48: 1-7.

Schoolman G, Arndt H. 2017. "Leaf-litter preferences of the introduced freshwater shrimps Atyaephyra desmarestii and Neocaridina davidi." Crustaceana 90: 1715-1730.

Weber S, Traunspurger W. 2016. "Influence of the ornamental red cherry shrimp Neocaridina davidi (Bouvier, 1904) on freshwater meiofaunal assemblages." Limnologica 59: 155-161. 